\title{
Os textos clássicos e o movimento da história
}

Aroldo Alcantara de Paula SOUZA ${ }^{1}$

\section{RESUMO}

A leitura de textos clássicos no curso de pedagogia da UNAES foi o tema de uma pesquisa monográfica em 2007. Foi empreendida uma investigação sobre a instituição, o curso e sua biblioteca. Através da análise das ementas, grades e registro do acervo ficou constatado que a desvalorização do texto clássico não é um fenômeno restrito à sala de aula e que, duas disciplinas constituem-se como exceções em meio à regra geral: utilização de manuais didáticos, trechos de dissertações e fotocópias de capítulos de livros contemporâneos. Discurso, prática e linha de pensamento dos professores das disciplinas pesquisadas foram analisados com o objetivo de demonstrar que a vertentemarxista "ciência da história" pressupõe uma didática baseadana cientificidade histórica comum aos textos clássicos.

Palavras-chave: clássicos, manual didático, história da educação, filosofia.

\section{Introdução}

Todo educador, quando assume uma sala de aula, independente do nível de ensino, assume também um compromisso ético e profissional com a aprendizagem efetiva de seus alunos, além da sua própria. Segundo Demo (2007), o sucesso da prática pedagógica de um professor depende em muito de seu perfil: leitor completo (lê, adquire obras para sua biblioteca particular, socializa e seleciona, a partir de suas leituras, subsídios para suas próprias elaborações. Além disso, participa sistematicamente de seminários, capacitações e eventos de educação continuada, mantendo-se atualizado e empreendendo os primeiros passos rumo à composição de uma nova didática, necessária à superação de uma escola identificada por Gilberto Luiz Alves como manufatureira e anacrônica:

\footnotetext{
1 Prefeitura Municipal de Campo Grande - MS/Escola Municipal de Tempo Integral "Ana Lucia de Oliveira
} Batista". 
Sem que se dêem conta do fato, esses educadores vêm se comportando segundo uma rotina que os leva a repetir as mesmas práticas seculares, que a força do hábito petrificou em rituais religiosamente cumpridos. Mais precisamente, têm ignorado que o mundo se transformou à volta da escola, enquanto essa fortaleza aferrada ao passado tudo assiste impassível. Nesse sentido, se pode falar de uma tradição escolar marcada pelo sinete manufatureiro. ALVES (1998, p. 177)

Apesar da obviedade do valor do texto clássico, algumas variáveis operam no ato de decisão do educador de não servir-se de textos clássicos: a formação inicial do professor universitário não contemplou a leitura de textos clássicos e ele, naturalmente, não pode introduzir conteúdos desta natureza fortuitamente; os manuais didáticos trazem uma síntese de conhecimentos que "facilita" a veiculação do saber considerando o tempo disponível para o professor planejar, desenvolver e avaliar seu trabalho didático.

Além das variáveis expostas no parágrafo anterior, outras situações colaboram para que os clássicos continuem relegados para segundo plano nas instituições de ensino superior, explicando também o estado de imobilismo que toma conta de toda a comunidade acadêmica:

Por que a comunidade acadêmica não enfrenta estes problemas? (...)

0 público-alvo das disciplinas universitárias alterou-se radicalmente nos últimos 20 anos. Suas ambições pessoais e necessidades sociais reclamam uma nova didática e um redirecionamento de ementas e programas: torna-se imperativa uma adequação entre os conteúdos formais e os possíveis. Caso contrário declararse-á uma adesão incondicional à farsa! Vejamos. Algum professor de Economia Política ainda acredita na possibilidade de iniciar seus alunos nos pensamentos de Smith, Ricardo ou Marx? Algum professor de Introdução à Sociologia ainda imagina que seu público possa ser levado a ler, com proveito, as obras de Weber ou de Durkheim? (...) Nossa resposta geral é: não. Ao insistirem no caminho até hoje trilhado, professores e alunos permitirão um ainda maior estreitamento (aproximação) formativo entre o $2^{\circ}$ e $03^{\circ}$ graus. Em nome de um ensino universitário de qualidade negar-se-á todo o ensino. Em nome do conteúdo da educação negar-se-á a educação do conteúdo. MALAGUTI (2005, p. 2)

Estando esta instituição inserida no contexto descrito por Manoel Luiz Malaguti,, 
poderia ser considerado normal se, no primeiro semestre do curso de Pedagogia, numa aula de Fundamentos Filosóficos de Educação, por exemplo, o professor da disciplina buscasse no livro didático "Filosofando: introdução à filosofia", de Maria Lúcia de Arruda Aranha e Maria Helena Pires Martins, uma abordagem que julga conveniente para o entendimento por parte dos acadêmicos do pensamento político de Platão, quando poderia melhor fazer através da leitura e discussão de trechos ou na íntegra da obra clássica "A República", de autoria do próprio pensador grego:

Nas outras cidades, é natural que aqueles que se tornaram filósofos não participem nos trabalhos da vida pública, visto que se formaram a si mesmos, apesar do governo destas cidades; ora, é justo que aquele que se forma a si mesmo e não deve o sustento a ninguém não queira pagar o preço disso a quem quer que seja. Mas vós fostes formados por nós, tanto no interesse do Estado como no vosso, para serdes o que são: os reis nas colméias; demo-vos uma educação melhor e mais perfeita que a desses filósofos e tornamos-vos mais capazes de aliar a condução dos negócios ao estudo da filosofia. Por isso, é preciso que desçais, cada um por sua vez, à morada comum e vos acostumeis às trevas que aí reinam; quando vos tiverdes familiarizado com elas, vereis mil vezes melhor que os habitantes desse lugar e conhecereis a natureza de cada imagem e de que objeto ela é imagem, porque tereis contemplado verdadeiramente 0 belo, o justo e o bem. Assim, o governo desta cidade, que é a vossa e a nossa, será uma realidade, e não apenas um sonho, como o das cidades atuais, onde os chefes se batem por sombras e disputam a autoridade, que consideram um grande bem. PLATÃo (1997, p. 231)

0 texto acima foi extraído da parte final do livro VII, famoso por conter o "Mito da Caverna", espetacular alegoria através da qual Platão logra duplo êxito: procura validar, através de suas modalidades mais tradicionais, os diálogos e as alegorias, sua principal teoria filosófica, a "Teoria do Mundo das Idéias"; paralelo a isso, trata de convencer seus discípulos da superioridade de um sistema político que apenas admitisse a ascensão ao poder de reis-filósofos, ou seja, cidadãos-livres com grande capacidade intelectual. É também com razoável facilidade que se apreende através da fala de Platão a desagregação que existia entre as cidades-estado gregas, pois o futuro mestre de Aristóteles admite, inclusive, a existência de filósofos também nestas outras unidades 
gregas, mas admite problemas sérios em suas formações, muitas delas fundamentadas sob os conhecimentos dos sofistas.

0 século $\mathrm{V}$ foi considerado o século de ouro da Grécia, como ficou conhecido o período em que viveram Sócrates, Platão, Aristóteles, Aristófanes, Péricles, Protágoras, Sófocles, entre tantas outras personalidades gregas do período, também denominado socrático. Como aqueles eram tempos de uma educação preceptoral ${ }^{2}$, apenas uma reduzida parcela da população desfrutava do acesso ao conhecimento: a aristocracia grega. Abrem-se, então, espaços para a atuação dos sofistas, sábios errantes se locomoviam por todo o território grego da antiguidade em busca de uma seleta clientela que apresentasse condições materiais adequadas para o custeio sua própria educação. Atentos estudiosos da sociedade da época, então estabelecida em torno da Pólis e seus monumentos mais característicos, a Ágora e a acrópole, investiram seus saberes na preparação de homens que buscassem, individualmente, alcançar posição de destaque naquela sociedade, proporcionada através da exibição de uma eloquiência irretocável, o que justifica a alcunha de sofistas (indivíduos que se utilizam de sofismas ${ }^{3}$ ) atribuída pelos filósofos alinhados às teorias de Sócrates.

Ficou claro que a partir de um único objetivo, que consistia em compreender o pensamento político de Platão, a aula do curso de Pedagogia, baseada em textos clássicos, passou a contemplar outros conhecimentos importantes que enriqueceram o trabalho didático: história da Grécia, Aristóteles, sofistas, ideal de educação do grego antigo, cidade-estado grega. Disciplinas como Fundamentos Filosóficos da Educação e Didática deveriam representar um aporte teórico considerável à formação do futuro educador, mas, o que se observa na realidade é que, na própria formação para a docência e ao longo do exercício da profissão, um embate entre teoria e prática, como que se estivesse tratando de ações dicotômicas para o educador. Atenta a tal imbróglio, a Lei

${ }^{2}$ Uma relação educativa praticada entre dois indivíduos: o mestre ou preceptor, e o discípulo. As mais célebres ocorreram entre Sócrates e Platão; este último e Aristóteles, com a relação entre ambos não gozando de um final nada amistoso; Felipe II, rei da Macedônia (nação que dominou a Gréciaem 338 a.C., com a batalha de Queronéia) escolhe o também macedônico Aristóteles para exercer a preceptoria do herdeiro de seu trono, o jovem Alexandre, de 13 anos, que a partir dos 20 anos entraria para a história como "Alexandre, o Grande".

3 Ferreira (1999, p. 1875) traz como significados para a palavra sofisma: argumento aparentemente válido, mas, na realidade, não conclusivo, e que supõe má-fé por parte de quem o apresenta; falácia; argumento falso formulado de propósito para induzir outrem a erro; engano, logro, burla ou tapeação. 
9.394, promulgada pelo Congresso Nacional em 20 de dezembro de 1.996, que estabeleceu as Diretrizes e Bases da Educação Nacional (LDB), em seu título VI, artigo. 61, inciso I, prevê que "a associação entre teorias e práticas" (BRASIL, 1997) deve permear a formação dos profissionais da educação, ignorando a indissociabilidade existente entre teoria e prática.

Não apenas na formação inicial, mas também em eventos de educação continuada, como jornadas, oficinas, capacitações e congressos, é comum e desestimulante a solicitação dos participantes, educadores ou futuros educadores, que os ministrantes apresentem fórmulas prontas, na verdade, práticas desprendidas de quaisquer fundamentações. Nesses eventos, quando são realizadas oficinas baseadas em estudos teóricos, como são, por exemplo, 0 grupo de estudo, a mesa redonda ou o seminário, é comum o fato de este tipo de evento receber poucas inscrições, muitas vezes inviabilizando sua realização.

À medida que os educadores avançam a níveis superiores de estudos acadêmicos, como especialização, mestrado ou doutorado, passam a compreender a importância que exerce a fundamentação teórica em relação às práticas pedagógicas, justificando e ampliando suas aplicações e possibilidades, afastando qualquer semelhança com ações do tipo "livre-fazer", da prática desprovida de qualquer fundamentação. Atividades providas de tal antagonismo em relação à educação formal não possuem a capacidade de conduzir o educador à reflexão, além de não favorecer a veiculação do conhecimento científico, que segundo Saviani (1997, p. 18-19), é sinônimo de conhecimento sistematizado, erudito, socializado pela escola. Portanto, a prática combinada à teoria converte-se em uma desejável atitude do educador comprometido com vertentes contra-hegemônicas e verdadeiramente transformadoras, convertendo-se na tão almejada "práxis"."

Nos dias de hoje, discussões e reflexões sobre escola, sua didática e conteúdos (os clássicos, inclusive), professores e alunos, inevitavelmente apontam e sempre apontarão para inconsistências graves do modelo escolar proposto pelo sistema capitalista de produção, simplesmente porque professores e alunos dividem uma escola cujo

Significado para o verbete práxis segundo Ferreira (1999, p. 1622): filosofia. No marxismo, o conjunto das atividades humanas tendentes a criar as condições indispensáveis à existência da sociedade e, particularmente, à atividade material, à produção; prática. 
(...) principal ambiente do trabalho docente, a sala de aula, mostra a inadequação das ementas e dos programas atuais em relação às expectativas e possibilidades dos alunos. Os saberes e os conhecimentos consagrados deixaram há muito tempo de serem úteis ao imediatismo pragmático e à nova realidade do capital. 0 ensino das humanidades - nas Universidades periféricas e nos Centros de Excelência - exige hoje um conteúdo "ralo", disperso e elementar. É cada vez mais profundo o fosso entre a formação do antigo professor universitário e suas tarefas cotidianas. Ou seja, boa parte do conhecimento anteriormente necessário à formação de um professor de $3^{\circ}$ grau torna-se progressivamente supérfluo. A docência torna-se uma atividade rotineira e desestimulante. Seu exercício provoca decepção e desalento. MALAGUTI $(2005$, p. 7)

Instaura-se na universidade, que deveria ser o mais alto nível escolar, uma situação no mínimo ambígua: por um lado, busca-se formar um educador, consciente de que a escola pode ser tanto campo de luta ou de reprodução da ideologia dominante. Este é o discurso. Por outro lado, não se trabalha efetivamente em prol da preparação adequada deste educador, desde o período de formação inicial, muito menos depois, ao longo do exercício da docência, não the proporcionando os recursos mínimos necessários a um trabalho docente satisfatório.

Ocorre neste momento da pesquisa a superposição do discurso em tom de urgência deste último autor (Malaguti) e contribuições do professor Gilberto Luiz Alves. Outro historiador da educação, Pedro de Alcântara Figueira consegue realizar com racionalidade histórica a defesa de uma escola que se encontra em vias de superação:

Isto não desmerece a Escola, mas apenas mostra que ela perece enquanto instituição que faz parte da sociedade que se decompõe. Mas a verdade é que a nova sociedade ainda não tem, e nem pode ter, a escola condizente com os novos ditames e valores sociais. Tudo o que os mestres sabem se ordena ainda segundo a velha ordem social. FIGUEIRA (1995, p.12)

São vozes que anunciam, juntas, que o professor deve, com emergência, retornar à intelectualidade, com o objetivo de prosseguir em sua jornada de 
preparação para a edificação de uma nova didática. Figueira, inclusive, alerta aos formuladores das políticas públicas educacionais que, não serão em vão os investimentos realizados, pois este educador, mesmo que ocorra uma hipotética gênese de um novo modo de produção, tornar-se-á o pilar sob o qual se edificará todo este novíssimo edifício escolar.

Ao longo de todo este artigo, nos vinculamos à vertente marxista denominada "ciência da bistória". Este termo foi detalhado por Karl Marx e Friedrich Engels em uma tão simples e ao mesmo tempo rica e esclarecedora nota de rodapé da obra "Ideologia Alemã":

"Conhecemos apenas uma única ciência, a ciência da História. A história pode ser considerada de dois lados, dividida em História da natureza e história dos homens. No entanto, este dois aspectos não se podem separar; enquanto existirem homens, a história da natureza e a história dos homens condicionam-se mutuamente. A história da natureza, a chamada ciência da natureza, não é a que aqui nos interessa; na história dos homens, porém, teremos de entrar, visto que quase toda a ideologia se reduz ou a uma concepção deturpada desta história ou a uma completa abstração dela. A ideologia é, ela mesma, apenas um dos aspectos desta história." MARX \& ENGELS (2004, p. 11)

\section{Uma visão marxista sobre educação e os clássicos}

0 educador que opta por utilizar textos clássicos em seu trabalho didático, inserido na escola contemporânea ${ }^{5}$, veicula saberes vitais aos estudantes da disciplina, oportunizando a estes o contato com conhecimentos que, segundo Saviani (1986, p. 24), conduzirá o futuro educador à reflexão filosófica, que deve ter como principais características ser radical, rigorosa e de conjunto.

Esta desejável composição entre saberes - textos clássicos que veiculando o conhecimento científico - e atitudes - reflexão filosófica - conduzirá ao entendimento da realidade, pré-requisito para implementação de quaisquer transformações.

5 Cambi (1999, p. 377) convenciona que a idade contemporânea inicia-se em 1789, com o advento da Revolução Francesa, que elimina o Antigo Regime e favorece a um dinamismo social, ideológico, político etc. Paradoxalmente, enquanto sua gênese é marcada por revoluções e guerras globais (islâmica, as duas grandes guerras mundiais), a industrialização das nações e a ampliação dos direitos humanos são outras várias faces desta vital fase histórica. 
Eis que surgem os textos clássicos como instrumentos primordiais para que acadêmicos e futuros educadores possam realizar uma correta leitura da sociedade contemporânea, graças às suas características como documentos peculiares:

Por serem repositórios de informações originais e, sobretudo, por revelarem as contradições sociais referentes à época em que foram produzidas, tais fontes convertemse em privilegiados para a reconstituição histórica no plano do pensamento. Daí o porquê da utilização sistemática de obras clássicas e documentais, neste trabalho, visando iluminar a época que se tem em vista. ALVES (1998, p. 28-29)

Verdadeiramente, os textos clássicos representam o essencial, enquanto que as interpretações, os manuais didáticos, as apostilas e toda a gama de adaptações compõem tão somente uma frágil aparência, que é disponibilizada pela escola contemporânea aos seus educandos por professores que optam, de maneira talvez inconsciente e alienada, por tais materiais e conteúdos, afinados com o sistema econômico capitalista. É urgente a mudança, pois

(...) os homens têm sempre criado representações falsas sobre si próprios, e daquilo que são ou devem ser. Segundo as suas representações de Deus, do homem normal, etc., têm instruído as suas relações. Os filhos da sua cabeça cresceram-lhe acima da cabeça. Curvaram-se, eles que são os criadores, diante de suas criaturas. Libertemo-los das ficções do cérebro, das idéias, dos dogmas, das essências imaginadas sob cujo jugo se atrofiam. Rebelem-nos contra o domínio das idéias. Ensinemo-los a trocas essas fantasias por idéias que correspondem à essência do Homem, diz um; a terem uma atitude crítica face a elas, diz o outro; a expulsá-las da cabeça, diz o terceiro; - e a realidade vigente ruirá. MARX \& ENGELS (2004, p. 7)

Superfluidade, anacronismo e perversidade são apenas algumas das características do sistema de produção material em vigência no atual período da história da humanidade: capitalismo. Considerando-se todos os campos do conhecimento humano que investigam a gênese, desenvolvimento e derrocada dos modos de produção - sociologia, economia, história, educação, geografia - nenhum outro autor o fez como o alemão Karl Marx (1818-1883). Em vários 
escritos, tornou explícita a realidade de sistemas baseados na exploração da classe menos favorecida, uma luta encarniçada entre as classes e a ascendência da produção material da sociedade sobre o pensar e agir dos seus indivíduos.

A formação do homem e seus diversos componentes referentes à educação, tais como escola, saber científico, alunos, professores e trabalho didático, enquadram-se, segundo a teoria marxista - ocupada em explicitar e superar 0 capitalismo - na categoria de instituição superestrutural do sistema, determinada pelos móveis da infra-estrutura econômica. As ideologias aparecem como produções a serviço da infra-estrutura, que intermedeiam o pensamento dos homens visando resigna-los às situações de exploração desmedida. Na verdade e em todos os tempos, este pensamento sempre correspondeu ao pensamento da classe dominante. No caso da atualidade, o pensamento da burguesia; a burguesia atual em muito difere daquela que, nos idos do século XIX, logrou êxito em estabelecer as bases da hegemonia que ora presenciamos.

Sobre a questão de o pensamento predominante da sociedade corresponder exatamente ao pensamento da burguesia e as relações humanas converteremse em relações de produção, Marx esclarece que

Na produção social de sua vida, os homens assumem determinadas relações necessárias e independentes de sua vontade, relações de produção que correspondem a uma determinada fase de desenvolvimento de suas forças produtivas materiais. 0 conjunto dessas relações de produção forma a estrutura econômica da sociedade, a base real sobre a qual se ergue a superestrutura jurídica e política e à qual correspondem determinadas formas de consciência social. 0 modo de produção da vida material condiciona o processo da vida social, política e espiritual em geral. Não é a consciência do homem que determina o seu ser, mas, ao contrário, é o ser social que determina sua consciência. MARX (1991, p. 276)

As lutas de classe sempre existiram em todos os modos de produção que a humanidade já experienciou: entre escravizados e aristocratas rurais na antiguidade (Grécia e Roma são exemplos); servos e senhores feudais na Idade Média; e mais atualmente, proletariado e capitalistas. Sobre a veracidade e gravidade de tal luta, Karl Marx, no clássico "Manifesto do partido comunista" concluiu que: 
A história de toda sociedade até os nossos dias é a história da luta de classes.

Homem livre e escravo, patrício e plebeu, senhor e servo, mestre e oficial, em suma, opressores e oprimidos sempre estiveram em constante oposição; empenhados numa luta sem trégua, ora velada, ora aberta, luta que a cada etapa conduzia a uma transformação revolucionária de toda a sociedade ou ao aniquilamento das duas classes em confronto. MARX, (2001, p. 23-24)

0 conceito marxista para história dos homens interessa de sobremaneira a esta reflexão, pois a trajetória dos textos clássicos - sua aceitação ou refutação - se confunde com a dos homens que os escreveram ou utilizaram em suas reflexões pedagógicas e/ou filosóficas:

(...) temos de começar por constatar a primeira premissa de toda a existência humana, e portanto, também, de toda a história, ou seja, a premissa de que os homens têm de estar em condições de viver para ((fazer história)). Mas da vida fazem sobretudo comer e beber, habitação, vestuário e ainda outras coisas. 0 primeiro ato histórico é, portanto, a produção dos meios para a satisfação destas necessidades, a produção da própria vida material, e a verdade é que este é uma ato histórico, uma condição fundamental de toda a História, que ainda hoje, tal como há milhares de anos, tem de ser realizado dia a dia, hora a hora, para ao menos manter os homens vivos. (...).

0 segundo ponto é este: a própria primeira necessidade satisfeita, a ação da satisfação e o instrumento já adquirido da satisfação, conduz a novas necessidades - e esta produção de novas necessidades é o primeiro ato histórico.

(...)A terceira relação, que logo desde o início entra no desenvolvimento histórico, é esta: os homens, que, dia a dia, renovam a sua própria vida começam a fazer outros homens, a reproduzir-se - a relação entre homem e mulher, pais e filhos, a familia. MARX \& ENGELS (2004, p. 30-32)

\section{Em busca de um conceito para os clássicos}

A mais contundente definição de clássico foi enunciada por Gilberto Luiz Alves, em um artigo com o título "As funções da escola pública de educação geral sob o imperialismo": 
Clássicas são aquelas obras de literatura, de filosofia, de política, etc., que permaneceram no tempo e continuam sendo buscadas como fontes do conhecimento. E continuarão desempenhando essa função pelo fato de terem registrado, com riqueza e minúcias e muita inspiração, as contradições históricas de seu tempo. Elas são produções ideológicas, pois estão estreitamente ligadas ás classes sociais e os interesses que delas emanam, mas são também meios privilegiados e indispensáveis para que o homem reconstitua a trajetória humana e descubra o caráter histórico de todas as coisas que produz. (ALVES, 1990, p. 112)

Diversos textos acadêmicos defendem a primazia dos textos clássicos com relação à educação escolar, muitos deles chegando a receber a classificação elogiosa de "clássicos contemporâneos", apenas por que, embora se tratando de obras em recente edição, acabam por alcançarem grande repercussão em meio acadêmico, contendo conhecimentos úteis tanto à formação inicial dos educadores quanto aos níveis de pós-graduação. Como exemplos destes estes "clássicos contemporâneos" podem ser citados "A produção da escola pública contemporânea" (1998), de Gilberto Luiz Alves, "Educação e luta de classes" (1963), de Aníbal Ponce; "História da educação: da antiguidade aos nossos dias" (1989), de Mario Alighiero Manacorda; "Escola e democracia" (1983) e "Pedagogia histórico-crítica: primeiras aproximações", de Dermeval Saviani. E justamente desta última obra pode ser extraída outra respeitada definição para o termo clássico em educação segundo o autor:

Clássico, em verdade, é o que resistiu ao tempo. É nesse sentido que se fala na cultura greco-romana como sendo clássica, que Descartes é um clássico da filosofia. (...)

(...) clássico na escola é a transmissão-assimilação do saber sistematizado. Este é o fim a atingir. (SAVIANI, 1997, p. 23)

0 dicionário Novo Aurélio Século XXI, de autoria do renomado lingüista Aurélio Buarque de Holanda Ferreira apresenta cinco definições muito úteis para a compreensão do termo clássico:

Clássico $=($ do latino classicu $)$ Adj. 1. Relativo à arte, à literatura ou á cultura dos 
antigos gregos e romanos. 2. Que segue em matemática de artes, cultura, o padrão desses povos. 3. Da mais alta qualidade; modelar, exemplar: definição clássica; atitude clássica. 4. Cujo valor foi posto à prova do tempo; tradicional; antigo: às tendências modernas preferem as formas clássicas da arte e literatura. 5. Que segue os cânones preestabelecidos; acorde com eles. FERREIRA (1999, p. 484)

Italo Calvino, ocupou-se em analisar as principais obras de alguns dos grandes escritores universais. Em 1984 concluiu sua mais conhecida obra: "Por que ler os clássicos". Esta obra trata-se da reunião de seus ensaios, publicados em jornais italianos ao longo das décadas de 60, 70 e 80, analisando os grandes livros da literatura mundial: Odisséia, de Homero; Cândido, de Voltaire; Metamorfoses, de Ovídio; só para citar alguns dos trinta e cinco títulos analisados ao longo da edição brasileira.

Na abertura deste livro, no artigo de 1981, cujo título empresta o nome à obra, o autor enumera quatorze propostas de definições ou razões de por que ler ou, como prefere o autor, reler um clássico. Seguem reproduzidas abaixo as definições que interessam a este artigo:

1. Os clássicos são aqueles livros dos quais, em geral, se ouve dizer: "Estou relendo..." e nunca "Estou lendo...".

2. Dizem-se clássicos aqueles livros que constituem uma riqueza para quem os tenha lido e amado; mas constituem uma riqueza não menor para quem se reserva a sorte de lê-los pela primeira vez nas melhores condições de apreciá-los. 3. Os clássicos são livros que exercem uma influência particular quando se impõem como inesquecíveis e também quando se ocultam nas dobras da memória, mimetizando-se como inconsciente coletivo ou individual.

4. Toda releitura de um clássico é uma leitura de descobertas como a primeira.

6. Um clássico é um livro que nunca terminou de dizer aquilo que tinha para dizer.

7. Os clássicos são aqueles livros que chegam até nós trazendo consigo as marcas das leituras que precederam a nossa e atrás de si os traços que deixaram na cultura ou nas culturas que atravessaram (ou mais simplesmente na linguagem ou nos costumes).

9. Os clássicos são livros que, quanto mais pensamos conhecer por ouvir dizer, quando são lidos de fato mais se revelam novos, inesperados, inéditos.

13. É um clássico aquilo que tende a relegar as atualidades à posição de barulho 
de fundo, mas ao mesmo tempo não pode prescindir desse barulho de fundo. 14. É um clássico aquilo que persiste como rumor mesmo onde predomina a atualidade mais incompatível. CALVINO (2005, p. 9-15).

\section{Sobre homens, clássicos e a educação de seu tempo}

Autores dos primeiros textos clássicos, o maior mérito dos primeiros gregos foi o de sistematizar com competência os primórdios do conhecimento humano, criando para isso condições materiais adequadas, suportadas por meio de uma sociedade escravista. A partir de então, uma elite pôde dedicar-se à reflexão, que culminou na tão propalada racionalidade.

Exemplificam muito bem a vitalidade dos textos clássicos as antiqüíssimas

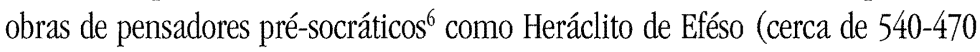
a.C.) e Parmênides de Eléia (cerca de 530-460 a.C.) ou de Homero ${ }^{7}$ (século IX a.C.), ainda atualmente utilizadas no aprendizado de diversas áreas do conhecimento: educação, lingüística, história, geografia, sociologia, filosofia, entre outras. No caso dos pré-socráticos, seus escritos foram submetidos a um sem número de percalços, chegando aos dias atuais sob a forma de escassos fragmentos ou citações doxográficas ${ }^{8}$ inclusas em obras de autores e comentaristas posteriores, como é o caso dos pré-socráticos.

Homéricos, atomistas, pré-socráticos, socráticos, pós-socráticos, epicuristas e estóicos são categorias ou formas de agrupar os pensadores, de predominância grega, que se debruçaram sobre a tarefa de compor a base de conhecimentos que impulsionou o homem grego na passagem do pensamento mítico ao pensamento racional. A edificação deste cabedal de saberes iniciou-se com os

\footnotetext{
6 Segundo Chauí (2002, p. 53-54) são pré-socráticos os filósofos que predominavam na Grécia no século IV a.C., tendo sido alguns de seus representantes contemporâneos de Sócrates, tais como Anaxágoras, Zenão e Árquitas. São escolas filosóficas gregas cuja discussão principal compreendia a phýsis grega, ou seja, conhecimentos sobre a cosmologia, a física, a natureza e a constituição das coisas. A autora-filósofa os classifica em quatro tendências, ou como prefere, escolas, que não existiram numa sequiência determinada, mas chegaram a coexistir: a Jônica (representantes: Tales de Mileto e Heráclito de Éfeso); Pitagórica (Pitágoras de Samos e Árquitas de Tarento); Eleata (Parmênides e Zenão, ambos de Eléia); Atomista e/ou da Pluralidade (Leucipo e Demócrito, ambos de Abdera e Empédocles de Agrigento e Anaxágoras de Clazómena).

7 As datas de nascimento e falecimento de Homero são extremamente incertas, bem como sua própria existência, alimentando acaloradas discussões entre os mais renomados historiadores da academia.

8 Segundo Ferreira (1999, p. 707) este verbete significa compilação filosófica ou a arte do doxógrafo, que foi "cada um dos compiladores gregos que utilizavam em seus escritos extratos dos filósofos antigos".
} 
relatos orais de aedos ${ }^{9}$ e rapsodos de acontecimentos reais ou fictícios. São belos exemplos destes conteúdos a Odisséia e a Ilíada, de Homero - relatos antiqüíssimos da pré-história grega - e lendas como Prometeu e Édipo, coletadas, organizadas e formalmente escritas, respectivamente, pelos grandes trágicos gregos Ésquilo e Sófocles. Narrativas passadas de geração em geração, que constituíram o grande patrimônio cultural desta civilização, sob o qual foi alicerçado o maior projeto educacional da antiguidade: a Paidéia. Werner Wilhelm Jaeger (1888-1961), célebre helenista alemão e autor da obra-prima "Paidéia: a formação do homem grego", define logo na primeira página de seu livro que a palavra Paidéia:

(...) é a única designação exata do tema histórico nela estudado. Este tema é, de fato, difícil de definir (...). 0 seu conteúdo e significado só se revelam plenamente quando lemos a sua história e lhes seguimos o esforço para conseguirem plasmar-se na realidade. Ao empregar um termo grego para exprimir uma coisa grega, quero dar a entender que essa coisa não se contempla, não com os olhos do homem moderno, mas sim com os do homem grego.

Não se pode evitar o emprego de expressões modernas como civilização, cultura tradição, literatura ou educação; nenhuma delas, porém, coincide realmente com 0 que os Gregos entendiam por Paidéia. Cada um daqueles termos se limita a exprimir um aspecto daquele conceito global e, para abranger o campo total do conceito grego, teríamos de empregá-los todos de uma só vez. JAEGER (1986, p. 1)

Os clássicos da civilização grega fundamentaram os saberes dos grandes pensadores da civilização ocidental. Baseados nos conhecimentos filosóficos de estudiosos como os pré-socráticos, seguiram-se outros estudiosos como os sofistas, os filósofos alinhados a Sócrates (destaque para Platão e Aristóteles), os epicuristas ${ }^{10}$ e estóicos ${ }^{11}$, seguidos de uma constelação de pensadores latinos,

\footnotetext{
9 Segundo Ferreira (1999, p. 58 e p. 1706) aedos e seus similares, os rapsodos eram poetas da Grécia antiga que, cantavam ou declamavam suas composições religiosas ou épicas.

${ }^{10}$ José Américo Motta Pessanha, em 1978, no volume da coleção "Os Pensadores" que reúne traduções dos textos originais do grego Epicuro e dos latinos Lucrécio, Cícero Sêneca e Marco Aurélio, produziu um estudo introdutório e bibliográfico sobre o fundador do epicurismo e sua escola filosófica: este pensador nasceu em 341 a.C., tendo sido discípulo de acadêmicos e atomistas. Professor de gramática e filosofia no entorno da Grécia antiga, em 306 a.C. funda sua escola em Atenas - 0 Jardim de Epicuro. Apesar de viver gravemente enfermo, era dono de uma personalidade inovadora, terna e amável, tendo sido, mesmo após sua morte, venerado por seus discípulos, entre
} 
que tão bem estruturaram o cabedal de conhecimentos da antiguidade.

Sobre clássicos, educação, história e homens, Alves (2005, p. 41-58) registrou a relação entre educação formal dos homens e a (não) utilização de textos clássicos. Procurou analisar detidamente o fecundo período histórico compreendido entre o humanismo e o iluminismo, intermediados por um período de luta entre as igrejas católica e protestante, que representava na verdade, uma luta travada em nível infra-estrutural: de um lado a burguesia e de outro as forças do Antigo Regime. Nesta obra é pormenorizado que em períodos como o humanismo de Erasmo de Roterdam, os clássicos foram revitalizados e 0 acesso a pensadores gregos e latinos estimulado. A partir do Plano de Estudos idealizado por Erasmo, constata-se que 0 ensino vigente preservava ainda uma forma basicamente feudal - preceptoral - e estava colocado um embate histórico, localizado temporalmente como a transição entre 0 antigo regime - 0 feudalismo - e o capitalismo. A burguesia, como classe emergente, e a nobreza, em franca decadência, tendo a igreja como aliada de longa data, duelavam, respectivamente, a primeira em prol de seu nascimento e confirmação; a segunda buscando uma sobrevida.

0 plano de estudos humanista detinha uma riqueza de conteúdos que foi perdida na Reforma e na Contra-reforma, pois seus educadores acreditavam que as línguas antigas - 0 grego e o latim - continham uma espécie de código necessário ao domínio do saber da antiguidade e sistematicamente recomendavam 0 acesso às obras clássicas originais, sem adaptações ou sequer traduções. Com relação ao currículo, os humanistas ministravam aulas de gramática latina e retórica, nesta ordem, pois a primeira fornecia conhecimentos para 0 desenvolvimento da segunda. Em ambas as cátedras os clássicos e boas antologias serviam como recursos às aulas, não exercendo um controle ideológico, função relegada ao mestre preceptor.

Em clara oposição ao Humanismo, a Contra-Reforma, empreendida

eles, Lucrécio. Divulgava uma filosofia de caráter empirista como o único acesso à verdadeira felicidade e 0 conhecimento, libertando o homem de todo medo dos deuses e da morte.

${ }^{11}$ Estoicismo, segundo Padovani e Castagnola (p. 145-149, 1990): escola filosófica pós-socrática fundada por Zenão (334-262 a.C.), de Citium, Chipre. Funda sua escola em Atenas no ano 300 a.C., tendo seu nome sido originado na palavra grega stoá - pórtico, em português - o local da polis onde os conhecimentos estóicos eram ensinados. Os estóicos praticam uma filosofia moralista e política com o firme objetivo de proporcionar ao homem a virtude e a felicidade necessária à vida coletiva da Polis, ineditamente formada, além dos cidadãos, de estrangeiros, inimigos e escravos. 
pela Igreja Católica e disseminada pela Companhia de Jesus, manteve de forma abrandada os clássicos a serviço da escolástica, plataforma de trabalho ao mesmo tempo educativa, ideológica e teológica, expurgando e censurando estes textos de acordo com os interesses da Santa Sé. Os educadores jesuítas não reconheciam os pensadores antigos, pagãos e politeístas, como origem do saber, pois essa função ficava relegada aos componentes espirituais do conhecimento, esses tidos como infalíveis e inquestionáveis. Seu plano de estudos, o Ratio Studiorum, apresentava uma predominância do latim, com alguma dedicação ao hebraico, língua largamente utilizada no estudo da Bỉblia original, com o grego sendo colocado em segundo plano e para o ensino de retórica eram selecionados obras de poetas, oradores e historiadores gregos e latinos. Inclusive quanto ao ensino de gramática, retórica e filosofia, buscou-se inspiração na obra de Aristóteles, via interpretação de S. Tomás de Aquino, compondo a doutrina filosófica denominada escolástica.

Rubano \& Moroz (2000, p. 145-158) esclarecem que cristianizar textos pagãos não foi uma atitude inédita para os pensadores católicos, pois, anteriormente, em plena passagem do Império Romano - decadência do modo de produção escravista - ao feudalismo, outro grande teórico da Igreja, Santo Agostinho, Bispo de Hipona (África romana), criou sua filosofia, a Patrística - a filosofia cristã dos primeiros padres da Igreja - a partir de profundas leituras dos textos de Platão.

Sistematicamente, os educadores contra-reformistas mantiveram um acirrado combate aos ideais burgueses de sociedade, pois é inegável que ao longo do movimento de toda a história, o acesso ao conhecimento sempre representou para as classes, frequentemente em luta, uma forma de poder.

Frequientadora assídua do seleto grupo de "vencedores" desta modalidade de luta de classes, a Igreja Católica, desde o Império Romano dos tempos de Constantino - 392 d.C. - manteve-se como aliada das classes dominantes, não nutrindo nenhum interesse em educar quaisquer classes emergentes, como, escravos, servos ou burgueses. Tal demonstração de animosidade refletiria nas atitudes e pensamentos de pensadores modernos ligados à burguesia, já em fase de consolidação. Destacam-se como exemplos os idealizadores de movimentos como a Revolução Francesa e a unificação tardia dos Estados nacionais (Maquiavel). Estes, desde a gênese de suas teorizações, previam uma incisiva laicidade no nascedouro de suas instituições nacionais. 
A Reforma, no papel de grande crítica da Igreja Católica, condenou a atitude desta em abrigar sob sua doutrina textos de origem pagã, terminando por impor uma censura ainda mais rígida, chegando às raias da eliminação. Inimigos declarados da Igreja Católica, reformadores como Ratke, Coménio e Lutero não cansavam de denunciar a decadência e os vícios dos opositores confessionais, julgando como culpados os textos clássicos e seus autores. Esses ricos conteúdos, inclusive os originais, foram sumariamente descartados, 0 que implicou em perda de saberes. Houve mesmo um retorno à patrística, com a Bíblia assumindo o papel de texto-chave para o ensino reformador.

Ao longo da história, muitos homens dedicaram suas vidas e trabalhos à produção e manuseio de textos clássicos voltados às necessidades da educação do período em que viveram. Alguns destes modelos chegaram a servir de modelo para a educação das gerações futuras. Um dos mais destacados teóricos, que colaborou na composição da história da educação foi João Amós Coménio ${ }^{12}$ que, cinco séculos atrás, ocupou-se em projetar uma nova e inédita ordem escolar que julgava adequada às necessidades de seu tempo, determinado materialmente pela eclosão da manufatura:

15. A arte de ensinar nada mais exige, portanto, que uma habilidosa repartição do tempo, das matérias e do método. Se a conseguirmos estabelecer com exactidão, não será mais difícil ensinar tudo à juventude escolar, por mais numerosa que ela seja, que imprimir, com letra elegantíssima, em máquinas tipográficas, mil folhas por dia, ou remover, com a máquina de Arquimedes, casas torres ou qualquer outra espécie de pesos, ou atravessar num navio o oceano e atingir 0 novo mundo. E tudo andará com não menor prontidão que um relógio posto em movimento regular pelos seus pesos. COMÉNIO (1996, p. 186)

Coménio, no capítulo XXV de sua "Didáctica magna", que leva o longo título de "Se realmente queremos escolas reformadas segundo as

\footnotetext{
${ }^{12}$ Durante a elaboração deste artigo, o autor defrontarou-se com duas grafias da língua portuguesa (de origem latina, portanto) para a o nome do maior educador da Reforma: Coménio e Comenius. Gilberto Luiz Alves utiliza, respectivamente, as duas formas em suas obras "A produção da escola pública contemporânea" (1998) e "0 trabalho didático na escola moderna: formas históricas" (2005). Esta pesquisa optou pela grafia Coménio, em concordância com Joaquim Ferreira Gomes, tradutor para a língua portuguesa da "Didáctica Magna" para a editora portuguesa da Fundação Calouste Gulbekian.
} 
verdadeiras normas do autêntico cristianismo, os livros dos pagãos, ou devem ser afastados das escolas, ou ao menos devem ser utilizados com mais cautela que até aqui". Expõem, sob o ponto de vista da Reforma protestante, o encaminhamento merecido pelos clássicos, em especial aos de origem greco-romana, ou pagã:

17. Nos livros dos filósofos, dos oradores e dos poetas, está contida uma grande sabedoria. Respondo: são dignos das trevas aqueles que desviam os olhos da luz. É certo que à coruja o crepúsculo parece o meio dia, mas os animais nascidos para a luz, conhecem-na bem diversamente. 0 homem fútil, que procuras a luz clara nas trevas do raciocínio humano, levanta os olhos para o céu! De lá desce a luz verdadeira, do Pai das luzes.

(...) Se os escritores pagãos não ensinam rectamente a Teologia, ensinam porém, a filosofia, a qual não pode haurir-se da Sagrada Escritura (...). A verdadeira filosofia não consiste senão no verdadeiro conhecimento de Deus e das suas obras, e estas coisas não podem aprender-se em parte alguma com mais verdade que da boca de Deus.

(...) Cícero, Virgílio, Horácio e outros são honestos e graves. Respondo: Todavia, também estes desviam a mente de seus leitores, do verdadeiro Deus para os deuses e deusas (Júpiter, Marte, Neptuno, Vênus, Fortuna e outras divindades, sem dúvida fingidas).

(...)

Finalmente, se deve admitir algum dos pagãos em nossas escolas, seja Sêneca, Epíteto, Platão e outros semelhantes, mestres de virtude e de honestidade, nos quais há a notar um menor número de erros e de superstições. Era este o conselho do grande Erasmo, que aconselhava se alimentasse a juventude cristã com as próprias Sagradas Escrituras, e finalmente acrescentava: $<<$ Se acaso ela deve demorar-se na literatura profana, quanto a mim, gostaria que se demorasse naquela parte que está mais próxima da literatura revelada >> (Erasmo, no Compêndio de Teologia)

(...)

Para terminar: aqueles autores (Terêncio, Cícero, Virgílio, etc.) que se pretende oferecer à juventude cristã, em vez da Bỉblia, são tais como eles afirmam que é a Sagrada Escritura: difíceis e menos inteligíveis que ela para a juventude. Efectivamente, não foram escritos para adolescentes, mas para homens de juízo 
maduro, que se movem já no palco ou no foro. (...) Porque é que então se não remete para um tempo oportuno o estudo destes clássicos importantes, se de facto são importantes? COMÉNIO (1996, p. 373-397)

Coube ao sacerdote protestante João Amós Coménio (1592-1670), na magnífica obra-prima, a "Didáctica magna" (1657), contida no tomo I das "Opera Didactica Omna", documentar a gênese do grande opositor do texto clássico: o manual didático. Este recurso tecnológico, tido atualmente como um "avanço" e uma "conquista" do alunado, não escapa à análise crítica do Professor Gilberto Luiz Alves, que vem se tornando um especialista em destruir quaisquer ilusões ou fantasias tão comuns sobre educação, livros-texto, saberes e competências:

"Comenius (...) projeta 0 estudioso para o tempo presente, o que revela a fecundidade dos estudos históricos quando não se voltam ao passado só por diletantismo ${ }^{13}$. A sua obra coloca luzes para o entendimento radical das práticas escolares (...). Os estudiosos que mal arranham a superfície do real com essas expressões da moda, algumas tão inócuas quanto pedantes, não se dão conta que no âmbito do trabalho didático, típico da escola moderna e arraigado ainda às suas origens, continuam a ser utilizados os mesmos instrumentos criados ou aperfeiçoados pelo autor da Didáctica magna, em especial o manual didático, que domina e dá a tônica à atividade de ensino." ALVES (2005, p. 68-69)

0 grande mérito de Coménio foi prever que a humanidade demandaria de um novo modelo escolar para atender às necessidades emergentes ocasionadas pela ascensão e preeminente hegemonia do novo modo de produção: a manufatura. 0 educador morávio nunca perdeu de vista que o aparelho educacional deveria ser estabelecido segundo os princípios de necessidade e viabilidade que norteavam o pensamento da burguesia, recém promovida à proprietária dos meios de produção. 0 que causa perplexidade a Alves é perceber, no decorrer de sua pesquisa científica, que o modelo escolar comeniano adquiriu uma sobrevida espantosa. Foi idealizado em pleno século XVII e

13 Ferreira (1999, p. 682) Significado de diletantismo: que ou quem se ocupa de qualquer assunto, ou exerce uma arte, por gosto, como amador, e não por ofício ou obrigação. 
operacionalizado apenas no período da Escola Nova, chegando à atualidade repleto de elementos anacrônicos e contraditórios, sofrendo grande carga de críticas. Apesar de tudo, o modelo conserva uma força invejável, desafiando as inteligências pedagógicas mais brilhantes, que não conseguem emplacar suas tendências inovadoras e progressistas.

Determinadas produções acadêmicas, além de responderem às questões propostas com fundamentação teórica, rigor e contextualização histórica, dobram em importância quando seu texto procura expor considerações sobre o método de pesquisa, neste caso, o método da "ciência da bistória". Este é 0 caso do trabalho das pesquisadoras Arruda et al (2003, p. 113-114) intitulada "Sobre (o) viver de crianças e adolescentes: uma reflexão acerca do método de pesquisa”, na qual afirmam que "(...) foi a leitura dos clássicos que permitiu captar o movimento da história, pelo relato dos homens que a viveram". Estas pesquisadoras, concluíram que a cientificidade histórica exigida pela teoria marxista também apontava para os textos clássicos como única alternativa viável a uma correta leitura da sociedade. Deseja-se compreender o pensamento dos gregos da antiguidade? Dedique-se à leitura de Homero ou Hesíodo. Caso o objeto de pesquisa seja o nascedouro do liberalismo, a leitura do inglês John Locke é indispensável.

Luiz Jean Lauand, respeitado medievalista, que organizou a antologia de textos medievais "Cultura e educação na idade média" (1998). Além da seleção e tradução dos textos, 0 autor imprimiu sua marca pessoal na obra através de uma introdução em que versa sobre os descaminhos do acervo cultural da humanidade ao longo da história e a difícil missão aceita por educadores de todas as épocas em perpetuar esse acervo. 0 pesquisador traça um paralelo entre os eventos ocorridos em tempos medievais e na atualidade, em face do quadro de aviltamento dos ideais educacionais. 0 texto traz ainda considerações sobre 0 alto grau de comprometimento do intelectual e educador romano Anício Mânlio Torquato Severino Boécio (c. 480-525) em relação aos clássicos de sua época:

Pensemos, por exemplo, nos bárbaros analfabetos que se instalavam no espaço do ex-Império Romano. Que faziam com os livros? Que acesso físico (obter os manuscritos), motivacional, de língua etc. tinham os ostrogodos e visigodos à 
cultura clássica? Quem contempla o panorama educacional brasileiro percebe imediatamente que o ostrogodo é uma realidade atual, atualíssima. Tal como no século VI, o perigo que enfrentamos é o do simples desaparecimento da cultura greco-romana que plasmou o Ocidente. Quem lê e compreende a fundo, hoje, Platão, Aristóteles, Virgílio, Cícero, Agostinho, Tomás de Aquino, Dante?

No caso da experiência medieval, a cultura antiga foi salva. Graças a um trabalho de imenso valor, que hoje poucos sabem apreciar, graças a um trabalho humilde, básico e necessariamente pouco original, a cultura antiga foi preservada (...). E graças também, como é de supor, à disposição de aprender não totalmente ausente dos povos bárbaros.

E graças, sobretudo, a educadores com grande visão pedagógica, dentre os quais é paradigmático o caso de Boécio, um romano que conhecia a cultura grega como ninguém, mas, sabia que, naquele momento, o esplendor do mundo cultural antigo já se tornara coisa do passado. A realidade à sua frente era uma só: os ostrogodos!

Para compreendermos como Boécio se sentia no reino ostrogodo de Teodorico, no início do século VI, precisaríamos imaginar como se sentiria hoje um brilhante scholar europeu que, embora dominando todas as áreas do pensamento, tivesse que lecionar num supletivo de primeiro grau em Cochabamba.

Boécio percebeu a tarefa a ser feita. Só conseguiria contribuir para a salvação da cultura ameaçada adaptando-a à modesta capacidade dos bárbaros. E por isso assumiu a tarefa de selecionar, traduzir, transmitir em forma de bê-á-bá os grandes tesouros culturais da Antiguidade. Tencionava traduzir todas as obras de Platão e Aristóteles, projeto interrompido pela trágica morte, e escreveu breves tratados resumidos de Música, Aritmética e Geometria, entre outros. LAUAND (1998, p. 2-4).

\section{Referências}

ALVES, Gilberto Luiz. As funções da escola pública de educação geral sob o imperialismo. Rev.Novos Rumos, São Paulo, 1990, n. 16. p. 112.

- A Produção da Escola Pública Contemporânea. Campinas, SP: Ed. Universidade Estadual de Campinas, 1998.

O Trabalho Didático na Escola Moderna: formas históricas. Campinas, SP: Autores Associados, 2005. 
ARRUDA, Elcia Esnarriaga de; LIMA, Maria de Fátima Evangelista Mendonça; PEREIRA, Sonia Maria; SOUZA, Ana Aparecida Argüelho; Sobre (o) viver de crianças e adolescente: uma reflexão acerca do método de pesquisa. Rev. Intermeio, Campo Grande, v. 9, n.18, p. 105-117, 2003.

BRASIL. Lei $n^{\circ}$ 9.394, de 1996. Lei de diretrizes e bases da educação nacional. Brasília: Gráfica do Senado Federal, 1997.

CALVINO, Italo. Por que ler os clássicos? São Paulo: Companhia das Letras, 2005.

CAMBI, Franco. História da pedagogia. São Paulo: UNESP, 1999.

CHAUÍ, Marilena. Introdução à história da filosofia: dos pré-socráticos a Aristóteles. São Paulo: ed. Companhia das Letras, 2002.

COMÉNIO, João Amós. Didáctica magna: tratado da arte universal de ensinar tudo a todos. Lisboa: Fundação Calouste Gulbekian, 1996. Trad. Joaquim Ferreira Gomes.

DEMO, Pedro. Aprender mal. (no prelo) 2007.

FERRO, Mário. TAVARES, Manuel. Conbecer os filósofos: de Kant a Comte. Lisboa: Ed. Presença, 1991.

FERREIRA, Aurélio Buarque de Holanda. Novo Aurélio século XXI: o dicionário da língua portuguesa. Rio de Janeiro: ed. Nova Fronteira, 1999.

FIGUEIRA, Pedro de Alcântara. A educação de um ponto de vista bistórico. Rev. Intermeio, Campo Grande, 1995, v. 1, n.1, p. 11-15, 1995.

HUBERMAN, Leo. História da riqueza do bomem. São Paulo: Livro Técnico, 1987.

JAEGER, Werner Wilhelm. Paidéia: a formação do homem grego. São Paulo: Martins Fontes, 1986.

LAUAND, Luiz Jean (org). Cultura e educação na idade média: textos dos séculos V ao XIII. São Paulo: Martins Fontes, 1998.

MALAGUTI, Manoel Luiz. “O fim do ensino?”. s.l.: 2005 (artigo fotocopiado)

MARX, Karl. Contribuição à crítica da economia política. In Clássicos da política. Org. Francisco C. Weffort. São Paulo: Ática, 1991.

MARX, Karl; ENGELS, Friedrich. Manifesto do partido comunista. Porto Alegre: L\&PM, 2001.

A ideologia Alemã. Teses sobre Feuerbach.

São Paulo: Ed. Centauro, 2004. 
PADOVANI, Umberto; CASTAGNOLA, Luís. História da filosofia. São Paulo: Melhoramentos, 1990.

PESSANHA, José Américo Motta. Os pré-socráticos: vida e obra. In Os pré-socráticos: fragmentos, doxografia e comentários. São Paulo: Abril Cultural, 1978. Col. Os pensadores. PLATÃo. A República. São Paulo: Ed. Nova Cultural, 1997.

ROSA, Maria da Glória de. A bistória da educação através dos textos. São Paulo: Cultrix, 1975.

RUBANO, Denize Rosana; MOROZ, Melania. O conbecimento como iluminação divina: Santo Agostinho. In ANDERY et al. Para compreender a ciência: uma Perspectiva Histórica. Rio de Janeiro: ed. Espaço e tempo; São Paulo: Educ, 2000, p. 145-158.

SAVIANI, Dermeval. Educação: do senso comum à consciência filosófica. São Paulo: Ed. Cortez e Autores Associados, 1986.

Pedagogia histórico-crítica: primeiras aproximações.

Campinas, SP: Autores Associados, 1997. 


\section{The classical texts and the movement of the history}

ABSTRACT

The reading of classical texts in the course of teaching of UNAES was the subject of a research monograph in 2007. Was undertaken on a research institution, the course and its library. Through analysis of menus, bars and record of the collection was found that the devaluation of the classic text is not a phenomenon restricted to the classroom, and that two subjects are to be exceptions in the midst of the general rule: use of teaching materials, parts of dissertations and photocopies of book chapters contemporaries. Discourse, practice and line of thought of teachers of the subjects studied were analyzed with the aim of demonstrating that the strand Marxist "science of history" requires a teaching based on common historical scientificity to classical texts.

Key-words: Classic, manual didactic, history of education, philosophy. 